\title{
INCIDÊNCIAS DA CONTRARREFORMA DO ESTADO BRASILEIRO NA POLÍTICA DE EDUCAÇÃO SUPERIOR: UMA ANÁLISE CRÍTICA
}

\section{Doniêgo Ferreira de Lima ${ }^{1}$ Cibelly Michalane Oliveira dos Santos Costa ${ }^{2}$}

Resumo: O presente trabalho configura-se como uma pesquisa exploratória de caráter bibliográfico, referendada na teoria social crítica. A priori, realizaram-se abordagens em torno das configurações econômicas, políticas, sociais e culturais resultantes do contínuo processo de contrarreforma do Estado brasileiro. Posteriormente, foram realizadas análises acerca das inflexões provocadas pelo referido processo de desmonte do Estado, com ênfase na política de educação superior, problematizando as peculiaridades que a referida política vem adquirindo a partir dos anos de 1990, momento de efervescência da espoliadora política neoliberal. Para tanto, abordou-se, enquanto consequência do neoliberalismo, os impactos que a educação vem sofrendo no cenário contemporâneo, a exemplo da expansão mercantil das instituições de ensino superior, da fragmentação e precarização do ensino, bem como o produtivismo acadêmico.

Palavras-chave: Contrarreforma; Neoliberalismo; Estado; Educação Superior. $\begin{aligned} & \text { 1Serviço Social/Universidade } \\ & \text { doniegolima@hotmail.com. }\end{aligned}$
$\begin{aligned} & \text { 2Serviço Social/Universidade } \\ & \text { cimichalane@hotmail.com. }\end{aligned}$ 